\title{
Experiences with Railway Regulation in Great Britain and the Czech Republic - Round Table Report $^{1}$
}

\author{
Chris Nash, ${ }^{2}$ Zdeněk Tomeš and Monika Jandová ${ }^{3}$
}

\begin{abstract}
The aim of the Round Table was to compare British and Czech experiences with railway regulation and competition introduction and to determine which lessons can be learnt. Special attention was paid to the question of whether the very complex British reform can be an inspiration for further liberalisation of the railway sector in the Czech Republic or whether there are any reform mistakes that are best avoided. Based on two introductory presentations and subsequent plenary discussion, some consensus emerged. The participants agreed that there is no one-size-fits-all solution to railway regulation and that the introduction of competition should take into account the different circumstances of a particular country. Franchising in passenger operations in Britain successfully stimulated demand but also increased costs to the industry, so its implementation should be completed with care. It seems very unlikely that open-access competition would be a viable solution for the whole passenger rail market because it is limited to a few commercially attractive routes, and as Czech experience suggests, it creates many new problems. Finally, it was confirmed that a strong and dedicated regulator is needed in a newly liberalised environment in order to solve many emerging conflicts and disputes.
\end{abstract}

Key words: Competitive tendering, Open access, Railway regulation, Franchising

JEL Classification: L92, L98, K23

\section{Introduction}

The round Table on railway regulation was organised at Masaryk University in Brno on September 18,2015 . The theme of the roundtable was the railway regulation experienc-

\footnotetext{
${ }^{1}$ The research was supported by the TACR grant TD020010: "Optimalizace a zefektivnění zadávání a kontroly veřejných soutěží v osobní železniční dopravě v ČR v kontextu společných politik EU" (Optimisation and increase in efficiency of the procurement and control of the public tenders in the passenger railway transport in the Czech Republic in the context of common EU policies).

${ }^{2}$ Institute for Transport Studies (ITS), Lifton Villas, 1-3 Lifton Place, University of Leeds, C.A.Nash@its.leeds.ac.uk

${ }^{3}$ Masaryk University, Faculty of Economics and Administration, Department of Economics, Lipová 41a Brno 602 00, Tomes@econ.muni.cz, jandova@econ.muni.cz.
}

( 2015 by the authors; licensee Review of Economic Perspectives / Národohospodárský obzor, Masaryk University, Faculty of Economics and Administration, Brno, Czech Republic. This article is an open access article distributed under the terms and conditions of the Creative Commons Attribution 3.0 license, Attribution - Non Commercial - No Derivatives. 
es in two EU countries - Great Britain and the Czech Republic. There were two introductory presentations; the first was given by Professor Chris Nash from the University of Leeds, who reviewed the British experience. The second presentation was by Zdeněk Tomeš from Masaryk University, who reviewed the Czech experience. After these presentations, Monika Jandová from Masaryk University moderated the discussion with the aim of highlighting lessons from the British and Czech cases and formulating recommendations for public policy.

\section{Presentations}

The first presentation was given by Professor Chris Nash on the topic "Rail Reform the British Experience". He started with a brief overview of the dramatic changes to the British railway system that happened in the 1990s. The British approach to rail reform was based on a complete separation of infrastructure and operations, and the existence of a strong independent regulator (ORR). In the passenger sector, Britain chose privatisation through franchising by means of a competitive tender (see Smith et al., 2009). In the case of rail freight, it was privatised with open access. The speed of the initial privatisation process and the lack of a state-owned operator - which is unique in Europe make the British approach distinct.

Nash focused on passenger franchising that typically consists of net cost contracts for 7 years with the possibility of a three-year extension when both the government and the franchisee desire. A franchisee is usually responsible for providing rolling stock that they have leased. There are two problems due to the relatively short franchise length: first, it could lead to higher prices unless the government bears a residual risk; second, there could be a lack of innovation.

Next, Nash summarised the impacts privatisation had on passenger railways in Britain. Privatisation is usually considered a great success based on the number of passengers transported. Passenger kilometres on the system have doubled since privatisation. However, as Nash noted, there could be other determinants of this tremendous growth, for example, economic growth, reduced competition from road traffic (caused by the slow growth of car ownership, congestion leading to longer road travel times, and rising petrol costs), reduced rail fares and improved rail services (partly the result of government decisions rather than franchisees). Conversely, there is a question of railway costs. The British approach was based on the economic rationale that if we introduce competitive tendering while the private sector bids for contracts, costs decrease. However, that has not happened in Britain. The cost per train kilometre in the passenger sector has increased in real terms by 25 percent. The majority of the growth was caused by infrastructure costs, but train operation costs have also increased (see Smith and Nash, 2014). However, things are going in the right direction now, particularly for infrastructure. Nash believes that the way forward in Britain is through reform of the franchising pro- 
cess and the introduction of close integration of a franchisee and an infrastructure manager. ${ }^{4}$

Nash mentioned other British problems, the first being that British franchises are typically too large (see Wheat and Smith, 2015). Next, there are problems managing franchise failure, some costs such as fuel costs, increases in insurance and policing and a large increase in staff costs that is partly due to competition for skilled staff. Finally, there is insufficient alignment of incentives between infrastructure and operations (see McNulty, 2011). The McNulty report stated that no one had looked at the whole British system and the parties involved had not been able to optimise it as a whole. Nash summarised the McNulty (2011) recommendations. The Report aims to achieve a $30 \%$ reduction in costs by $2018 / 9$ and to introduce closer links between railway bodies and bodies attached - e.g., decentralisation of Network Rail with regional concessions and closer links to train operators (possible leasing of infrastructure to operators) and increased local involvement in specification and funding. Finally, the Report suggests longer (at least 15 years), less highly specified franchises carrying more risk with revenue and infrastructure costs.

In July 2015, there was a new report from the Competition and Markets Authority (CMA, 2015). The aim of the British competition office is to enhance the competition of British rail. This should be done not only by franchising but also by emphasising ontrack competition through removal of constraints on entry, splitting franchises into two, and more creating overlapping franchises.

Nash suggested that the British problems can be solved not by extending the open access competition, but by reforming franchises. His detailed suggestions depend on the circumstances. Long franchises are necessary whenever a franchisee is responsible for service development, procuring rolling stock and influencing infrastructure investment (at least 20 years). Short gross-cost franchises may make sense when the franchising authority is responsible for asset procurement, marketing, influencing working practices, etc. He emphasised that the alliances with Network Rail had been crucial - ideally including total sharing of changes in revenue and cost.

Next, Nash discussed British rail freight, in which the reforms were much simpler and easier. As has been mentioned, British rail freight was privatised with open access. He considered rail freight competition to be quite successful, as it had given customers options, and the productivity of labour and rolling stock had increased (doubling of the mean train loads, especially in the case of coal and containers, and a large increase in labour productivity). In addition, the British rail freight had succeeded in re-entering some markets - e.g., food for supermarkets and post. According to Nash, though complete privatisation and open access in freight was a success, it was by no means a solution for passenger railways.

\footnotetext{
${ }^{4}$ Chris Nash claims that complete separation of infrastructure from operations has been problematic. That is why he suggested that alliances with the primary operators and parts of the network rail may be a solution.
} 
The second presentation was given by Zdeněk Tomeš on the topic "Rail Reform - the Czech Experience". Tomeš claimed that, in comparison to the British "big bang approach", the Czech railway liberalisation was a slow and gradual transformation. The major turning point in the Czech railway reform was in January 2003 when institutional vertical separation occurred. However, this vertical unbundling was incomplete, as it took a further five years to move infrastructure maintenance and timetabling from the incumbent to the infrastructure manager and network traffic was controlled by the incumbent until 2011. As Tomeš emphasised, even today (in 2015), Czech railway stations are owned by the incumbent, and this slow and patchy transformation is delaying fully effective liberalisation of the industry (Tomeš et al., 2014).

The development of rail passenger traffic after the fall of communism was characterised by the gradual decline of the volume transported and modal shares. However, after 2010 there was a trend reversion with growing passenger demand and rising modal share. This development was partially caused by an open access competition on the crucial Prague - Ostrava line, where intensive competition of three operators decreased prices, improved services and attracted ridership. The open access competition is allowed on the whole Czech railway passenger network, however, due to low commercial potential it is in operation only on the Prague - Ostrava line. All other passenger rail traffic in the Czech Republic is subsidised, and the usual form of procurement has been the direct award of subsidised services to the incumbent České dráhy. The long distance traffic is organised by the Ministry of Transport and regional traffic is organised by regional traffic authorities. Tomeš noted that even if the regional authorities had tried to tender some subsidised lines in a competitive manner, the number of tenders would still have been extremely low.

An important case study is the open-access competition on the Prague - Ostrava line, in which the first private operator RegioJet (from September 2011) and the second private operator LEO Express (from January 2013) have challenged the state-owned incumbent, České dráhy. The intense competition considerably improved the quality of services and service differentiation progressed greatly. Intense competition pushed down prices in the $2^{\text {nd }}$ class by $44 \%$ and in the first class by $20 \%$ (Tomeš et al., 2015). The frequency of services increased considerably (from 23 return trains in 2010 to 40 return trains in 2013). However, the higher number of trains was associated with a shorter length, putting economies of density in jeopardy. Tomeš estimated that demand had grown by $40 \%$ on this line between 2010 and 2013 and that in 2013, private operators were able to win $55 \%$ of the market share from the incumbent (see Tomeš et al., 2015). A change in the structure of the timetable is another effect of open access competition. This includes the gradual transformation from the regular interval timetable to the demand derived timetable with significant differences in frequency between peak and saddle times and with the reduction of late night trains. Finally, Tomeš generally assessed the pros and cons of open access on the Prague - Ostrava line. On the positive side, he named better quality of services, higher frequency of trains, and lower ticket prices. On the negative side, he listed weak regulation, no tariff integration, strains on infrastructure capacity, and questionable long-term sustainability. This was caused because not all competitors were able to break even financially. 
Tomeš concluded with some remarks concerning the Czech freight sector, in which the transported volumes are stable and modal share is declining. The dynamic competition of private operators has won a $24 \%$ market share (2013) in the whole rail freight market. According to Tomeš, the freight division of the incumbent is losing the most lucrative customers to private operators and suffers from under-investment and over-employment.

\section{Discussion}

Monika Jandová opened the discussion with a set of issues to be solved that developed into these questions:

- What are the key determinants of a successful franchise in Britain?

- Is the British model applicable to the Czech Republic?

- Is there a fit-to-all model for railways?

- Is open access a viable option for the Czech Republic and/or Britain?

- What should be the role of the railway regulator in the Czech Republic?

What are the key determinants of a successful franchise in Britain?

Chris Nash emphasised that there were two different approaches to franchising that can work under different circumstances. One is to give a lot of freedom, but also incentives, to a train operator to develop the market, perform marketing, etc. A relatively long net cost franchise with an operator bearing most of the revenue risk would probably be suitable for the commercial inter-city business. The other approach is for regional services that need subsidies. In this case, it should be the regional authorities that develop the service, perform the marketing, etc., and then let short gross cost franchises operate them.

The issue of geographical size and density can be included with some of the other issues. From a cost point of view, you do not want your franchises to overlap because it increases costs and you lose economies of density. Conversely, in terms of competition or providing attractive services for customers, there may be an argument for overlapping. There is another issue that should be solved, namely, the allocation of risk. In the British system, whoever wins the franchise has to put up the bond, and if he withdraws before the end of the contract, he loses the bond. Another way of withdrawing is to allow the train operating company to go bankrupt, but the British government also requires a guaranteed degree of underwriting from the parent company before that happens. Nash concluded that for Britain, it has been very difficult to get the balance right - how to attract newcomers and simultaneously what should be the penalties for withdrawing early, what should be the allocation of risk, etc.

M. Veselý asked about tariff integration in Britain. Nash answered that the British approach to tariff integration differs from that implemented in the Czech Republic. Initially, the government view was that rail privatisation was exactly the same as British bus privatisation and that operators should be free to decide what services they run and what fares they charge; thus, there was no integration at all. However, ultimately, the government was pushed to a more integrated approach. Consequently, there is a requirement to take part in integrated ticketing for both open access operators and franchisees. Now, it is possible to buy through tickets from anywhere to anywhere using any opera- 
tor in Britain. Conversely, Nash commented that the new entrants - the open access operators - have their own company-specific tickets, which are cheaper. Simultaneously, especially long-distance train operators have started to use the yield management system and sell their own advance purchase tickets for specific trains, thus receiving all of the money. Nash concluded that they have both the integrated system and some freedom for operators to offer cheaper ticket in Britain.

\section{Is the British model applicable to the Czech Republic?}

Nash emphasised that there was no reason that the approach to franchises used in Britain should not work in the Czech Republic. It is a way to introduce competition into the railway industry without problems with open-access competition. According to Nash, the Czech Republic should learn from British mistakes to improve their system to achieve success. T. Pospíšil from the Czech incumbent followed up by asking about the optimum size of a franchise. Nash noted that it seems to be a region-size franchise. He supposed that the optimum franchise is quite large, and in some cases (e.g., Norway), it could be the whole country.

M. Veselý, as the representative of the regional authority, referred to limited franchising experience between Czech regional authorities and asked about the size of the market of rolling stock in Britain and what the variety of rolling stock was. Nash stated that there were three main rolling stock leasing companies in Britain. However, the more recent trend consisted of dealing with the manufacturers in terms of the long-term contract, where it is the manufacturers who supply the funds, are responsible for maintenance, are responsible for providing the operator with services, etc. This is good for a long-term contract, but if a small company wants to lease some rolling stock for a contract with shorter effect, there is not much spare rolling stock in Britain.

\section{Is there a fit-to-all model for railways?}

Nash stressed that if we want to solve problems of national railways there are different solutions for different circumstances in a particular country. Under the "different circumstances" we should include the share of passenger and freight traffic in the national railway system, traffic density, the potential size of the open access competition, etc. The conclusion arising from this is that there is no fit-to-all model.

Is open access a viable option for passenger railways for the Czech Republic and/or Britain?

On this topic there was a wide consensus regarding the problematic nature of open access in passenger railways. Nash presented some open-access competition in Britain. However, even the limited British experience showed negative consequences such as insufficient track capacity, lack of integrated timetables and loss of economies of density. According to Nash, even if franchising in Britain had not provided the expected cost reductions, reforming franchising is more likely to achieve objectives than is extending the open access to passenger services.

\section{What should be the role of the railway regulator in the Czech Republic?}

In the discussion, Tomeš mentioned that railway competition issues are too complicated for the Competition Office. That is why a suitable solution is to establish an independ- 
ent railway regulator. He emphasised that Britain has greater experience with regulation, where, as Nash had reported, the strong regulator was capable of imposing penalties if something had gone wrong and discrimination had occurred.

\section{Conclusion}

Topics discussed on the "Railway Regulation" Round Table 2015 included both the British and Czech experiences with railway liberalisation and regulation, particularly the question of applicability of the British model of franchising in the Czech environment. Both countries shared experiences with open access competition. It was the existence of a strong independent regulator capable of dealing with complicated competition issues on rails in Britain in which the countries differed. Next, was that the liberalisation process itself had been much faster in Britain. What is quite inspiring is the model of franchising for the Czech passenger railway transport. If the Czech Republic follows the British example, it will be able to avoid British faults and introduce a system leading to higher efficiency, higher satisfaction of railway customers, and lower costs of the system. In the plenary discussion the participants agreed that there is no one-size-fits-all solution to railway regulation problems and that regulation should take the different circumstances of a particular country into account. Franchising can be an inspiration for other countries, but it should be implemented carefully as in Britain. It resulted not only in stimulation of demand but also in increasing costs. The commercial open access is creating new problems, and its function on the main line is not coexisting well with franchising in the rest of the network. Finally, there is a strong need for a dedicated regulator who is capable of solving frequent disputes.

\section{References}

CMA (2015). Competition in passenger rail services in Great Britain - A discussion document for consultation. Available on: https://assets.digital.cabinetof-

fice.gov.uk/media/55a8d1d6e5274a6fea000011/Passenger_rail_services_in_Great_Brita in.pdf.

MCNULTY, R. (2011). Realising the Potential of GB Rail - Final Independent Report of the Rail Value for Money Study. Department for Transport and Office of Rail Regulation, London. ISBN 978-1-84864-123-5.

SMITH, A. \& NASH, C. (2014). Rail Efficiency: Cost Research and Its Implications for Policy. Discussion paper 2014:22. International Transport Forum.

SMITH, A., NASH, C. \& WHEAT, P. (2009). Passenger rail franchising in Britain: has it been a success? International Journal of Transport Economics. 36(1), pp. 33-62.

TOMEŠ, Z., KVIZDA, M., JANDOVÁ, M. \& REDERER, V. (2015). Open access passenger rail competition in the Czech Republic. August 2015. Unpublished paper.

TOMEŠ, Z., KVIZDA, M., NIGRIN, T., \& SEIDENGLANZ, D. (2014). Competition in the railway passenger market in the Czech Republic. Research in Transportation Economics, 48, pp. 270-276. DOI: 10.1016/j.retrec.2014.09.052 
WHEAT, P.E. \& SMITH, A. (2015). Do the usual results of railway returns to scale and density hold in the case of heterogeneity in outputs: A hedonic cost function approach, Journal of Transport Economics and Policy. 2015:49, pp.35-47. 